\title{
Inovasi Sistem Pemisah Logam dalam Mendukung Pembangkit Listrik Tenaga Sampah (PLT Sampah)
}

\section{Innovation on Metal Separator System to Support Waste to Energy Generation (WtE)}

\author{
IIN PARLINA, WIHARJA, IIF MIFTAHUL IHSAN \\ Pusat Teknologi Lingkungan, Badan Pengkajian dan Penerapan Teknologi \\ Gedung 820 Geostech, Kawasan Puspiptek Serpong, Tangerang Selatan \\ Email: iin.parlina@bppt.go.id
}

\begin{abstract}
In the Waste to Energy (WtE) Pilot Plant system, the garbage feed has high diverse content including various type of metal. A metal separation system plays an important role during waste pretreatment process before the garbage entering the incinerator. This system is aimed to prevent performance degradation of the combustion system and to gain added value of the reuse metals in the waste. The WtE Pilot Plant in Bantargebang, constructed in 2018, is a large project and is expected to contribute significantly in overcoming waste problems in Indonesia. The performance of the WtE pilot plant system increases significantly if supported by a metal separator system integrated to the existing pretreatment system. This paper evaluates new design of metal separation system from the waste inputs. In general, metal separator system was designed as a permanent unit with a standalone or integrated electromagnetic lifting. In this paper, the metal separator system was designed by using a combination of permanent ferrite and neodymium magnetic cores to create a combined force able to pull scraps mixed in waste at a considerable distance and was easily removed and collected. To optimize the system, a metal separator system was attached to a crane system installed in a double cabin car. Thus, the flexibility of this system was increasingly high. Tests results showed that the metal separator system with a combination of ferrite and neodymium was able to pull metals in the waste from a distance up to $20 \mathrm{~cm}$ despite of blocking by non-magnetic wastes, and able to attract almost $100 \%$ of the exisiting metals.
\end{abstract}

Keywords: WtE, metal separator, ferrite, neodymium, waste, mobile system

\begin{abstract}
ABSTRAK
Pada sistem Pembangkit Listrik Tenaga Sampah (PLT Sampah), di mana umpan sampah memiliki keberagaman yang tinggi, termasuk keberadaan logam di dalamnya, sistem pemisahan logam sebagai tahapan pretreatment sampah sebelum masuk ke dalam sistem insinerator akan memegang peranan yang cukup penting. Sistem ini bertujuan untuk mencegah penurunan kinerja sistem pembakaran serta untuk meningkatkan nilai dari penggunaan ulang logam yang tercampur ke dalam sampah. Pembangunan Pilot PLT Sampah di Bantargebang yang dimulai pada tahun 2018 merupakan suatu proyek besar dan diharapkan dapat memberikan kontribusi yang signifikan dalam mengatasi permasalahan sampah di Indonesia. Kinerja sistem PLT Sampah ini akan lebih baik jika didukung oleh sistem pemisah logam yang dapat diintegrasikan dengan sistem pretreatment yang telah ada. Inovasi sistem ini dirancang untuk melakukan pemilahan terhadap input sampah yang masuk ke dalam sistem PLT Sampah yang berupa logam sehingga sampah logam tidak turut terbakar. Pada umumnya, pemisah logam dibuat sebagai unit permanen dengan menggunakan magnet pengangkat berupa elektromagnet yang berdiri sendiri atau bisa terintegrasi. Namun pada sistem ini, sistem pemisah logam dirancang dengan menggunakan magnet permanen yang menggabungkan inti magnet ferrite dan neodymium sehingga akan menciptakan kombinasi antara sistem yang dapat menarik scrap yang tercampur dalam sampah pada jarak yang cukup jauh namun bisa dilepaskan dengan mudah untuk dikumpulkan. Untuk membuat sistem ini bekerja optimal, sistem pemisah logam dibuat secara mobil dengan memadukannya dengan sistem derek yang terpasang pada sistem mobil kabin ganda. Dengan demikian, fleksibilitas sistem ini menjadi semakin tinggi. Uji yang telah dilakukan menunjukkan sistem pemisah logam dengan kombinasi ferrite- neodymium ini dapat menarik logam yang tercampur pada sampah hingga jarak $20 \mathrm{~cm}$ meskipun terhalang sampah yang lain (non-magnet), dan menarik hampir $100 \%$ dari logam yang tersedia.
\end{abstract}

Kata kunci: PLT Sampah, pemisah logam, ferrite, neodymium, sampah, sistem mobil 


\section{PENDAHULUAN}

Pembangunan

proyek

percontohan

Pembangkit Listrik Tenaga Sampah (PLT Sampah) di Bantargebang pada tahun 2018 adalah sebuah proyek besar yang diharapkan memberikan kontribusi yang signifikan dalam mengatasi permasalahan sampah di Indonesia. Pembangunan proyek percontohan PLT Sampah tersebut merupakan salah satu Proyek Strategis Nasional (PSN) berdasarkan Peraturan Presiden (Perpres) Nomor 58 Tahun 2017 tentang Perubahan atas Perpres Nomor 3 Tahun 2016 tentang Percepatan Pelaksanaan Proyek Strategis Nasional (PSN) untuk mewujudkan Nawacita dalam kehidupan bermasyarakat, berbangsa, dan bernegara. Hal ini dilatarbelakangi oleh fakta bahwa pada implementasinya, teknologi termal untuk penanganan sampah padat kota dengan sistem insinerasi untuk mengurangi volume sampah dan menghasilkan listrik dirasa kini sebagai salah satu solusi efektif untuk permasalahan sampah yang ada. Diperkirakan penerapan teknologi ini akan mengurangi volume sampah sekitar $90 \%$ dan massanya sekitar $70 \%{ }^{(1)}$. Untuk mewujudkan hal tersebut, Pusat Teknologi Lingkungan (PTL) BPPT menjadi kunci dalam proses eksekusinya.

Untuk mendukung keberhasilan proyek tersebut, perlu dikembangkan suatu sistem atau teknologi yang mampu mendukung kemandirian PLT Sampah. Dukungan dapat berupa peningkatan kinerjanya melalui pemilahan input sampah ke dalam sistem PLT Sampah, khususnya logam, sehingga sampah logam tidak turut terbakar di dalam sistem. Pembakaran logam di dalam sistem PLT Sampah tidak hanya akan menurunkan kinerja insinerator sampah tapi juga akan menghilangkan nilai dari logam yang sebenarnya bisa digunakan kembali untuk proses lain yang berdaya nilai lebih baik.

Selain itu, keberadaan logam terutama logam berat dalam input sampah sistem insinerasi dapat mengakibatkan timbulan partikel logam dalam bentuk fly ash melalui proses volatilisasi dan juga dalam bentuk bottom ash akibat proses pembakaran yang menghasilkan residu(2,3)

Terkait dengan proses pembangunan PLT Sampah, sistem pretreatment yang tepat untuk menunjang unjuk kerja dari proses juga harus ikut dikembangan dan ditinjau. Dalam kasus persampahan di Indonesia, metode pengelolaan sampah yang meliputi pengurangan sampah ditingkat produsen dan konsumen, pembakaran konvensional, penanganan (pemilahan, pengangkutan, pengolahan /pemusnahan dan pembuangan akhir) tidak terlalu efektif dalam menangani laju pertumbuhan sampah. Sehingga diperlukan teknologi pengolahan sampah yang dapat mengurangi sampah dalam volume yang besar dan waktu yang singkat.

Sampah padat kota memiliki heterogenitas yang tinggi baik dalam komposisi maupun ukuran partikel, sehingga akan berpengaruh pada proses pembakaran dan hasil residu akhirnya. Selain itu, kadar abu yang dimiliknya juga cukup tinggi dan dengan nilai jumlah kalor yang tinggi. Sampah logam yang terdapat dalam sampah domestik yang masuk ke TPST Bantargebang pada umumnya adalah sampah dengan ukuran yang relatif sedang hingga kecil, karena biasanya yang berukuran besar sudah diambil oleh para pemulung. Sampah logam yang berukuran besar ini bisa berupa sampah elektronik dan juga scrap dari bahan bangunan.

Logam dalam sampah ini tidak dapat dihancurkan, tetapi harus dipisahkan, dipadatkan, dan atau distabilkan dalam matriks limbah. Pemisahan dapat terdiri dari proses fisik dan kimia seperti penyaringan, pemisahan magnetik, pelindian, pertukaran ion, kristalisasi, distilasi, dan proses elektrokimia. Baik solidifikasi dan stabilisasi menurunkan mobilitas logam dan bertujuan mengurangi risiko pencucian logam in situ begitu limbah dibuang. Solidifikasi dicapai dengan pengikatan fisik seperti mikro-atau makro-enkapsulasi logam(3).

Insinerasi secara langsung akan membakar partikel limbah, termasuk logam, dengan udara berlebih, yang akan menghasilkan suhu nyala api lebih rendah jika dibandingkan dengan insinerasi pembakaran batubara dan biomassa. Ketika logam bercampur dalam sampah dan kemudian terbakar di dalam insinerator yang bekerja pada temperatur operasional sekitar $800-1000^{\circ} \mathrm{C}$, dengan karakteristik logam yang ada, maka ketika proses pendinginan, sampah logam yang ikut masuk akan menyebabkan terjadinya pengurangan kinerja. Abu dari pembakaran massa di fasilitas PLT Sampah ini kemudian akan dikeluarkan melalui beberapa jalur. Sebagian besar abu (biasanya $80-90 \%$ berat) adalah abu dasar (bottom ash) yang akan dibuang di bagian ujung perapian(4), Dalam satu paper disebutkan bahwa komponen utama dari abu dasar adalah kaca, logam magnetik, mineral, keramik sintetis, logam paramagnetik dan bahan organik yang tidak terbakar. Logam magnetik terakumulasi dalam fraksi ukuran partikel 1-6 $\mathrm{mm} \quad(6 \%$ dari fraksi ini). Logam berat terakumulasi dalam fraksi di bawah $1 \mathrm{~mm}$ dan hal ini akan menjadi masalah yang juga harus dicari penyelesaiannya(5).

Dengan demikian, pemisahan logam sebagai tahapan pretreatment sampah sebelum masuk ke dalam sistem insinerator diperkirakan akan mampu mencegah penurunan kinerja sistem pembakaran. Selain itu, hal ini juga berpotensi meningkatkan nilai lebih dari 
penggunaan ulang logam yang tercampur ke dalam sampah ${ }^{(6)}$.

Pada umumnya, sistem pemisah logam dibuat secara permanen dengan menggunakan magnet tipe elektromagnet dengan biaya instalasi dan operasi yang relatif tinggi(7). Penggunaan magnet permanen untuk sistem pemisahan logam pada sampah relatif lebih jarang digunakan. Magnet berinti neodymium atau lebih tepatnya neodymium-besi-boron ( $\mathrm{Nd}-$ Fe-B). merupakan salah satu dari empat kelas magnet permanen yang penting secara komersial yakni ferit, aluminium-nikel-kobalt (AINiCo), samarium-kobalt (SmCo), dan neodymium-besiboron $(\mathrm{Nd}-\mathrm{Fe}-\mathrm{B})^{(8)}$. Dibandingkan dengan magnet permanen ferit berikat, magnet neodymium memiliki beberapa kelebihan, diantaranya adalah dalam ukuran berat yang lebih kecil menunjukkan kinerja yang lebih baik sehingga biaya yang dibutuhkan menjadi berkurang. Oleh karena itu, magnet berikat berinti neodymium ini sekarang banyak digunakan dalam berbagai periferal komputer(9).

Namun sejauh ini, baru ada 1 paten yang menggunakan inti magnet neodymium sebagai magnet pengangkat (lifting magnet) yaitu paten dengan nomor seri US6854777B2. Penggunaan magnet neodymium sebagai magnet pengangkat (lifting magnet) digunakan dengan latar belakang magnet permanen konvensional dengan inti ferit yang memiliki kerapatan fluks magnetik di bawah 2.000 gauss. Sementara itu, untuk meningkatkan kinerja magnet sebagai magnet pengangkat, diperlukan magnet ferit yang relatif besar. Dengan rendahnya fluks magnet inti ferit, akan diperlukan ukuran yang relatif besar sehingga akan menghasilkan biaya produksi yang tinggi dan ruang yang lebih banyak. Oleh karena itu, penggunaan magnet neodymium yang memiliki kerapatan fluks magnet sekitar 10.000-13.000 gauss pertama kali diajukan. Kelemahannya hanya pada kemudahan teroksidasi ketika terkena atmosfer, namun masalah ini bisa diatasi dengan proses pelapisan permukaan magnet ${ }^{(10)}$.

Berdasarkan urgensi akan sistem pemisahan logam dalam PLT Sampah serta mempertimbangkan adanya kebutuhan dan keuntungan penggunaan pemisah logam yang bersifat mobile dengan menggunakan magnet permanen, maka tujuan dari kegiatan ini adalah terbangunnya sistem pretreament yang bergerak (mobile) dan fleksibel untuk memisahkan logam dari sampah yang akan masuk ke dalam sistem insinerator dalam PLT Sampah.

\section{BAHAN DAN METODE}

\subsection{Bahan dan Alat}

Sistem pemisah logam terdiri 1 buah derek merk Kevrek dengan tipe 700S (lihat Gambar 1) dengan sistem modifikasi magnet pemisah yang terdiri dari inti ferrite dan neodymium (lihat Gambar 2) yang dipasang secara permanen pada 1 unit mobil kabin ganda (Gambar 3). Sistem modifikasi magnet pemisah terdiri dari inti ferrite dan neodymium yang dirangkai sedemikian rupa sehingga bisa menarik logam dari campuran sampah dan melepaskannya dengan mudah.

Adapun bahan yang diujikan adalah sampah simulasi untuk uji pertama dan kedua serta sampah aktual yang berasal dari TPST Bantargebang untuk uji ketiga dan keempat. Untuk uji pertama, sampah simulasi ini terdiri dari sampah logam yang dicampur dengan sampah kering, kompos dan kertas yang semuanya bersifat kering, sedangkan untuk uji kedua, sampah simulasi terdiri dari campuran sampah logam dengan sampah yang lebih basah yaitu kompos, dan daun. Adapun sampah aktual TPST Bantargebang untuk uji ketiga dan keempat dipastikan memiliki kandungan logam di dalamnya.

\subsection{Metode}

Penentuan rangkaian sistem pemisah logam dilakukan dengan hipotesis bahwa inti neodymium yang dikombinasikan dengan inti ferrite dapat digunakan dalam proses pemisahan logam dan menjadi sebuah sistem inovasi baru dengan kinerja yang ebih baik.

Untuk mengevaluasi sistem ini, uji efektifitas sistem pemisah logam dilakukan sebanyak 4 kali dengan bahan sampah uji yang berbeda seperti dijelaskan pada bagian sebelumnya. Parameter yang menjadi sasaran uji dan level evaluasi adalah massa dari logam yang dicampurkan dan dipisahkan dari mekanisme pengujian. Pada uji pertama dan kedua, massa logam yang dicampurkan sudah diketahui dan setelah dipisahkan dengan alat pemisah logam, massa logam kembali ditimbang untuk dibandingkan. Pengukuran massa logam dan sampah dilakukan dengan menggunakan timbangan massa biasa. Pada penelitian ini digunakan timbangan bermerk Oxone OX366 yang memiliki kapasitas maksimum massa $15 \mathrm{~kg}$ dan skala 50 gram. . .

Adapun cara penggunaan sistem pemisah logam ini adalah dengan memposisikan derek dan magnet pada spot lokasi yang ditentukan, dilanjutkan dengan menggerak-gerakan derek dari panel secara otomatis (bagian-bagian derek dijelaskan pada Gambar 1). Derek digerakkan sedemikian agar tercipta sistem pengadukan yang mampu memperbesar posibilitas kontak antara magnet dengan logam yang terselip di antara campuran sampah. Setelah logam diperoleh, derek dengan magnet yang membawa logam yang terpisah digerakan ke arah spot lokasi pengumpul logam, selanjutnya tali yang 
tersambung pada magnet ditarik sehingga logam yang pada awalnya melekat pada magnet bisa terlepas dan dikumpulkan dalam bak pengumpul.

Uji pertama dan kedua adalah uji yang dilakukan untuk melihat unjuk kerja awal magnet pemisah logam juga evaluasi keseluruhan sistem derek dan mobilnya. Pada kedua uji tersebut, massa logam yang akan dicampurkan dihitung terlebih dahulu sebelum dilakukan pencapuran dan pemisahan lalu data dibandingkan dengan massa logam yang bisa ditarik setelah pemisahan logam dilakukan. Adapun sampah yang digunakan pada uji pertama adalah sampah simulasi, di mana scrap logam yang terdiri dari logam tembaga, besi, dan alloy dari berbagai ukuran (dengan berat awal logam yang dicampurkan sebesar 1,23 kg) dicampur dengan sampah kering berupa kertas dan rumput kering (sebanyak 0,68 kg) Sementara pada uji kedua yang ditujukan untuk melihat unjuk kerja magnet ketika digunakan untuk memisahkan logam yang tercampur dengan sampah yang agak basah atau dengan kadar air relatif lebih tinggi dari sampah uji pertama, sampah simulasi terdiri dari sampah organik daun-daun, kompos, tanah, dan logam. Scrap logam bahan pencampur yang digunakan untuk sampah simulasi masih sama yaitu $1,23 \mathrm{~kg}$.

Uji ketiga dan keempat adalah uji yang dilakukan untuk melihat unjuk kerja magnet pemisah logam terhadap sampah aktual yang merupakan sampah yang dibawa ke TPS Bantargebang sekaligus melihat unjuk kerja pemisah logam yang diintegrasikan dengan sistem pretreatment PLT Sampah yang ada (Gambar 4). Adapun sampah aktual yang digunakan merupakan sampah domestik warga dari berbagai area di Provinsi DKI Jakarta. Sampah logam yang tercampur ke dalam sampah asli ini biasanya berupa botol logam misalnya botol obat pembasmi nyamuk, kaleng makanan, tutup botol, paku dan serpihan logam tidak berbentuk, juga bekas alat dapur. Untuk kedua uji ini, sampah logam awal tidak diketahui karena tidak ada proses karakterisasi jenis sampah di awal kegiatan, Selain itu, heterogenitas sampah yang besar menyebabkan adanya kesulitan menghitung massa logam jika hanya mengandalkan dari proses sampling di satu atau lebih titik tertentu. Dengan demikian, yang diketahui hanya massa sampah total dan massa logam yang terpisah akibat proses pemisahan dengan alat ini.

Perbedaan uji ketiga dengan uji keempat adalah pada umpan sampah yang digunakan. Pada uji ketiga, umpan sampah aktual berasal dari sampah yang langsung diturunkan dari truk pengangkut sampah untuk masuk ke tahap belt coveyor (tahap 1 pada Gambar 4), dan hanya diketahui berat sampah total tanpa mengetahui jumlah kandungan logam yang ada di dalam sampah yang diperkirakan mencapai berat 15,2 $\mathrm{kg}$ untuk sampah pada space konveyor $1 \mathrm{~m} \times 0,5$ $\mathrm{m}$. Sedangkan pada uji keempat, sampah aktual berasal dari tahapan terakhir proses pretreatment sampah (tahap 3 pada Gambar 4) yaitu konveyor pemilah atau sorting conveyor.

Sistem pemisah logam dioperasikan pada batas waktu tertentu hingga permukaan magnet tertutupi oleh logam atau sampah yang ikut tertarik karena berada di antara logam dengan magnet. Setelah logam ditarik, dari belt conveyor, logam kemudian akan dikumpulkan dalam bak pengumpul.

Selain itu, karena dikawatirkan akan mengalami hambatan dalam aliran, sistem pemisah logam yang diintegrasikan dengan sistem pretreatmen dipasang pada jarak sekitar 5 sampai dengan $10 \mathrm{~cm}$ dari permukaan sampah yang mengalir di atas belt conveyor.

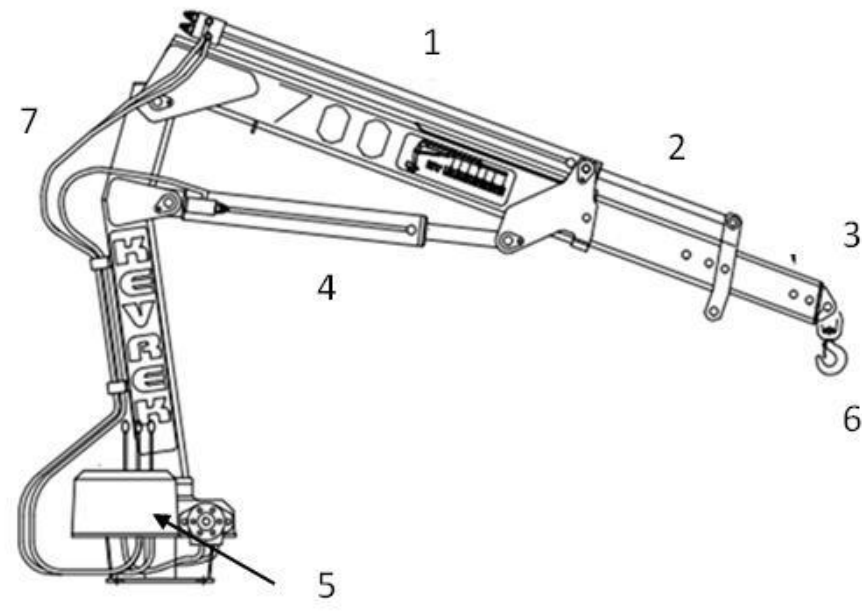

\footnotetext{
Keterangan Gambar

1: Boom Ekspander Utama

2: Boom Sekunder

3: Boom tersier

4: Katup pengontrol hidrolik

5: Panel Kontrol Operasi

6: Safety hook

7: Hydraulic Hoses
}

Gambar 1. Bagian untuk derek penggerak pada sistem pemisah logam beserta bagian-bagiannya 


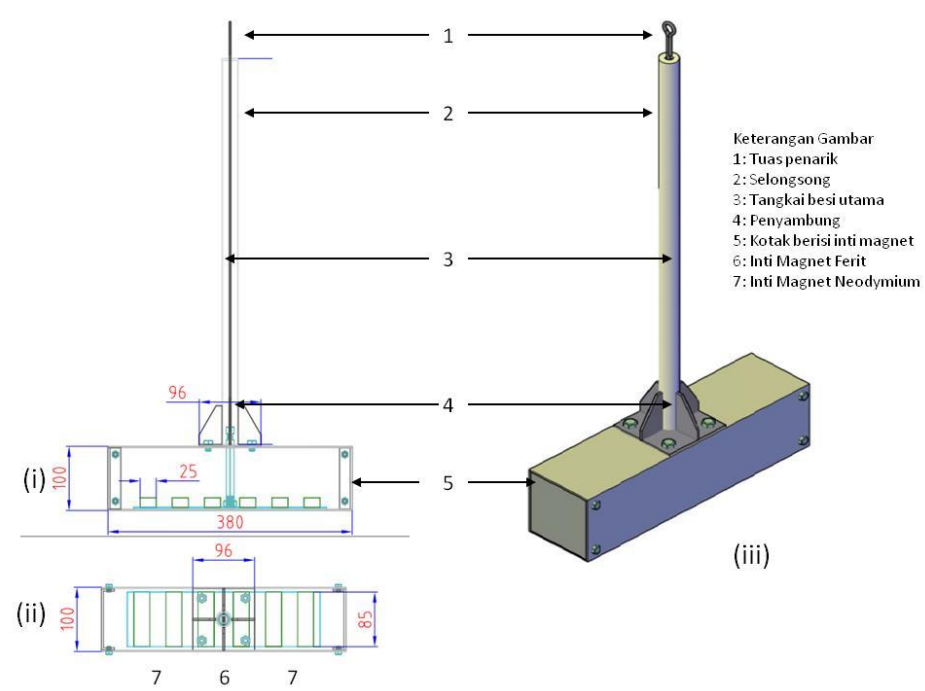

Gambar 2 Hasil pendekatan penggabungan inti magnet ferrite dengan neodymium pada rangkaian sistem pemisah logam. Tampak samping (i), Tampak atas (ii), dan penampakan dari luar sistem magnet permanen pemisah logam (iii)

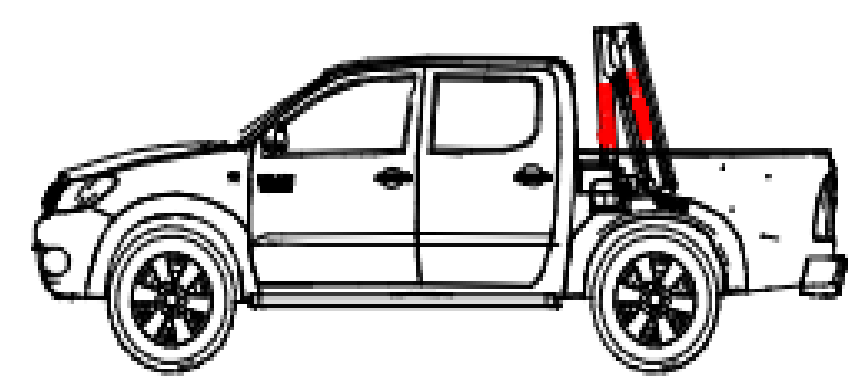

Gambar 3. Mobil kabin ganda sebagai tempat pemasangan sistem derek dan magnet pemisah logam

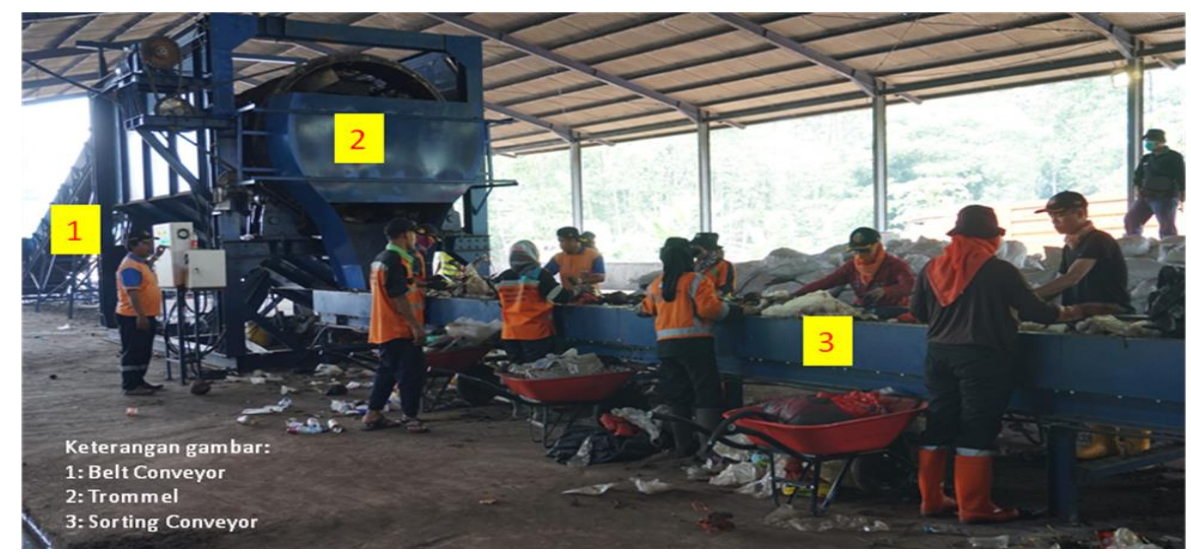

Gambar 4. Unit pretreatment PLT Sampah TPST Bantargebang di mana unit pemisah logam secara fleksibel bisa diintegrasikan di awal atau di akhir proses 


\section{HASIL DAN PEMBAHASAN}

Proses pengembangan sistem inovasi logam ini merupakan sebuah proses yang cukup panjang. Hal ini merupakan rangkaian proses berpikir untuk menyatukan sistem, magnet beserta semua opsi kombinasi yang mungkin, derek, dan mobil kabin ganda menjadi sebuah rancangan kombinasi yang tangguh, efektif, efisien, dan memiliki unjuk kerja yang baik dan mampu memenuhi sasaran tujuannya untuk menjadi langkah awal pemisahan logam dari sampah sebelum memasuki sistem PLT Sampah.

Ikhtisar hasil dari keempat uji untuk mengevaluasi unjuk kerja sistem pemisah logam mobile yang dikembangkan PTL BPPT dengan menggunakan magnet permanen kombinasi neodymium dan ferit disampaikan pada Tabel 1.

\subsection{Uji pemisah logam dengan menggunakan sampah kering dan sampah basah.}

Melalui uji pertama dan kedua dengan menggunakan sampah simulasi, sistem pemisah logam baik sistem derek dan sistem magnet dapat berjalan secara sinergis dan dapat dioperasikan dengan sangat baik. Dalam kedua uji tersebut, sistem magnet berhasil mengumpulkan hampir semua logam yang tersembunyi dalam campuran sampah simulasi bahkan tanpa dilakukan semi-pengadukan dengan menggerak-gerakan derek. Dari sampah logam yang sengaja dicampurkan, sekitar $96,75 \%$ logam bisa ditarik oleh magnet dan dikumpulkan dalam bak pengumpul. Sedangkan dalam uji kedua sekitar 94,31\% logam bisa dipisahkan dari campuran sampah simulasi. Masih adanya sampah logam yang tertinggal sebenarnya dapat direkayasa dengan menggerakkan derek dan melakukan sedikit pengadukan terhadap sampah sehingga sebenarnya bisa $100 \%$ terambil. Sehingga penyebab tidak terambilnya sisa logam diperkirakan bukan berasal dari lemahnya logam permanen yang dimiliki sistem magnet.

Dalam uji kedua juga dilakukan uji kejauhan jarak yang masih bisa ditarik oleh magnet, dan hasilnya adalah pada jarak $20 \mathrm{~cm}$ magnet tetap dapat secara optimal menarik logam dari campuran sampah. Tentunya lebih baik lagi jika kontak dilakukan kurang dari $20 \mathrm{~cm}$.

\subsection{Uji pemisah logam dengan menggunakan sampah aktual TPS Bantargebang terintegrasikan dengan sistem pretreatment}

Terdapat perbedaan yang signifikan antara sampah simulasi dengan sampah aktual berdasarkan karakternya. Sehingga memang penting melakukan uji langsung dengan sampah aktual untuk melihat aktual kinerja pemisah logam. Seperti yang dijelaskan pada bagian metode, uji ketiga menggunakan sampah langsung dari truk yang diumpankan ke belt conveyor, sementara uji keempat menggunakan sampah hasil pemilahan akhir di bagian pretreatment sampah PLT sampah TPST Bantargebang. Hanya saja, kesulitannya adalah tidak diketahuinya data awal logam ekisting yang tercampur dalam sampah aktual yang diujikan. Untuk uji keempat memang bisa dilakukan perhitungan massa logam yang tercampur di awal dengan melakukan perhitungan manual di akhir karena sampah yang diujikan menggunakan sistem umpan batch, sementara uji sampah ketiga tidak bisa dilakukan pengukuran massa logam total karena sistem sampah aktual yang diumpankan adalah continue.

Sebagaimana yang telah disebutkan sebelumnya bahwa sistem pretreatment memegang peranan yang cukup penting dalam keberhasilan unjuk kerja insinerator PLT Sampah dalam membakar sampah dan mengubahnya ke menjadi listrik. Namun pretreatment yang dibutuhkan bisa berbagai macam seperti termasuk di dalamnya pemisahan logam, pemisahan bahan bahan yang tidak boleh terbakar (misalnya B3 dan sejenisnya), juga bahan dengan kalor bakar rendah seperti tanah, air yang masih terkandung dalam sampah domestik Jakarta. Sistem pretreatment PLT Sampah menerapkan sistem pretreatment mekanis dengan menggunakan alat trommel screen yng berfungsi untuk memilah sampah berdasarkan ukuran yang ditentukan, serta mengurangi tanah yang masuk ke dalam sistem. Trommel ini didukung dengan adanya belt conveyor sebelum dan sesudah alat inti, dan di belakangnya dilakukan pemilahan manual oleh pekerja yang telah ditugaskan.

Kapasitas dari unit pretreatment ini dirancang untuk mampu menangani 100 ton/jam sampah meskipun pada kenyataannya, ada beberapa faktor yang menentukan kinerjanya. Misalnya saja, kapasitas hopper yang dipasang membuat sistem terbatasi untuk mampu menangani sampah sebanyak 5 ton/ jam. Sistem ini terus disempurnakan dan dioptimalkan untuk bisa mencapai target yang telah ditetapkan,

Adapun peran inovasi pemisah logam yang mobile dan fleksibel ini adalah bahwa alat ini mampu ditempatkan di depan atau di belakang unit trommel screen untuk mengurangi beban logam yang masuk ke dalam sistem insinerator. Hanya dengan memasangnya pada belt conveyor yang sedang berjalan, logam-logam yang ikut dalam aliran sampah akan bisa ditarik 
oleh magnet dan kemudian dikumpulkan. Adapun penggunaannya bisa dilihat pada Gambar 8.

Uji ketiga menunjukan bagaimana sistem pemisah logam harus dioperasikan sedemikian sehingga logam dalam aliran dalam unit belt conveyor bisa ikut dipisahkan sebelum masuk ke dalam unit trommel screen. Dalam uji ini, hanya diketahui logam yang bisa dipisahkan sebesar $1,09 \mathrm{~kg}$.

Pada uji keempat, diketahui massa sampah total yang diperoleh dari tahap akhir proses pretreatment adalah 5,90 $\mathrm{kg}$ dengan sampah logam yang berhasil dipisahkan sekitar $0,62 \mathrm{~kg}$ untuk satu periode operasi. Setelah dipisahkan, sampah yang dijadikan sampel uji dipilah secara manual dan diketahui ternyata masih ada sisa $0,05 \mathrm{~kg}$ logam yang tersisa dalam tumpukan sampel sampah. Diperkirakan jika dilakukan pengadukan yang lebih kuat, maka bisa saja sisa logam ini juga dapat ditarik magnet dalam satu periode operasinya.

Dari hasil uji integrasi yang ada dapat dilihat bahwa sistem ini bisa dikatakan dapat secara fleksibel terintegrasi dengan sistem pretreatment PLT Sampah yang sudah ada dan mampu menjalankan fungsinya memisahkan logam yang mengalir menuju atau setelah trommel screen secara baik pula.

Tabel 1. Ikhtisar hasil uji efektifitas pemisahan logam oleh unit pemisah logam PTL

\begin{tabular}{|c|c|c|c|}
\hline Uji & Parameter Kondisi Uji & $\begin{array}{c}\text { Rasio Parameter terhadap } \\
\text { Sampah Logam (kg:kg) }\end{array}$ & $\begin{array}{c}\text { Hasil Pemisahan logam } \\
(\mathbf{k g})\end{array}$ \\
\hline 1 & Sampah kering: sampah logam & $0,68: 1,23$ & 1,19 \\
\hline 2 & Sampah basah: sampah logam & $1,45: 1,23$ & 1,16 \\
\hline 3 & $\begin{array}{c}\text { Sampah TPST Bantargebang } \\
\text { (dimana logam sudah ada di } \\
\text { dalamnya) }\end{array}$ & $\begin{array}{c}\text { Tidak bisa ditentukan (berat } \\
\text { sampah total dari konveyor } \\
15,2 \text { kg) }\end{array}$ & 1,09 \\
\hline 4 & $\begin{array}{c}\text { Sampah TPST Bantargebang } \\
\text { (dimana logam sudah ada di } \\
\text { dalamnya) }\end{array}$ & $5,23: 0,67$ & 0,62 \\
\hline
\end{tabular}

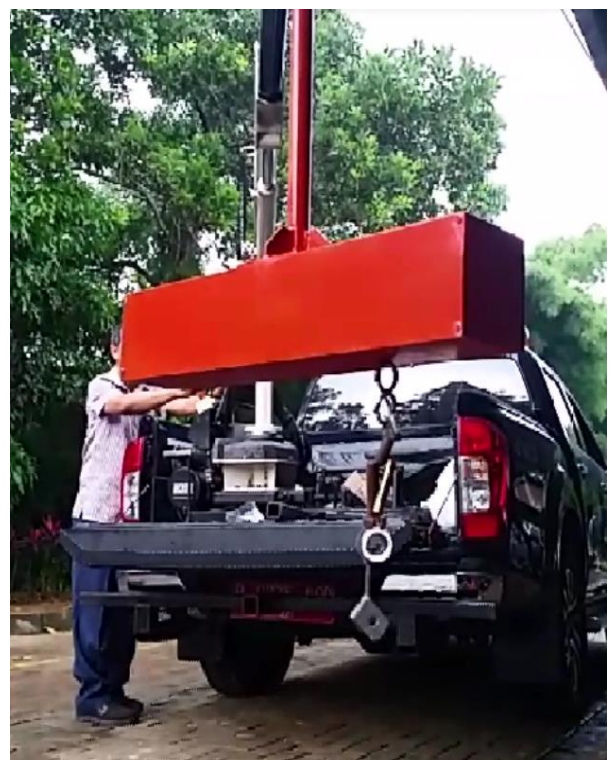

Gambar 5. Uji pertama dengan menggunakan sampah kering beradar air rendah 


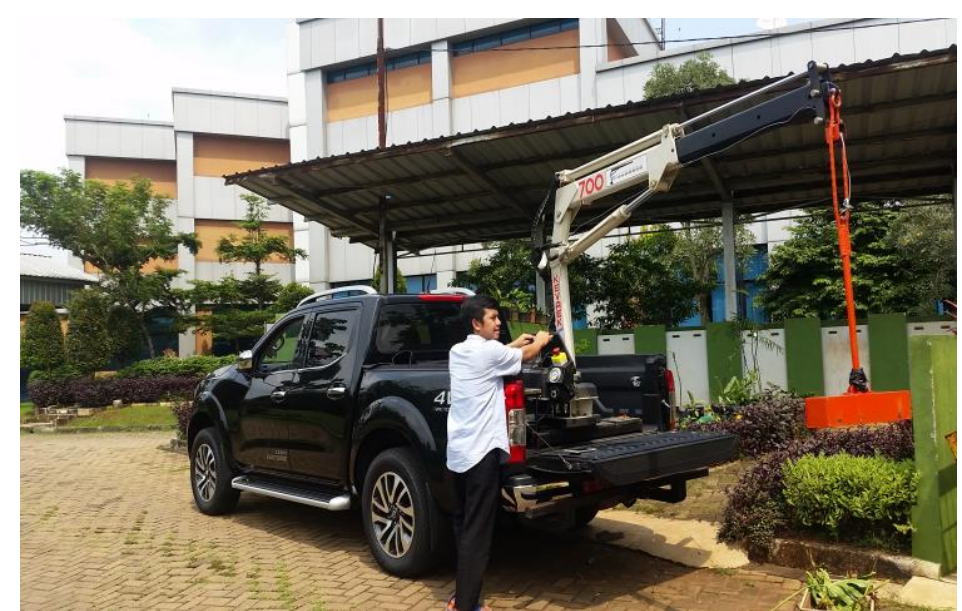

Gambar 6. Uji kedua dengan menggunakan sampah simulasi yang terdiri dari sampah logam, kompos, tanah, dan daun

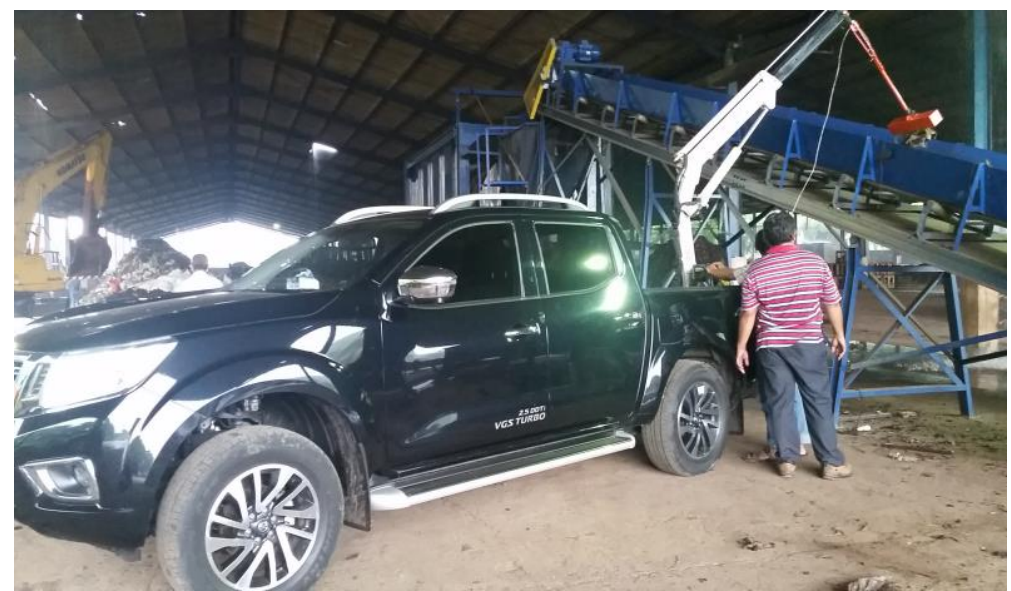

Gambar 7. Uji ketiga dengan menggunakan sampah aktual TPST Bantargebang dan diintegrasikan dengan sistem pretreatment PLT Sampah tahap awal

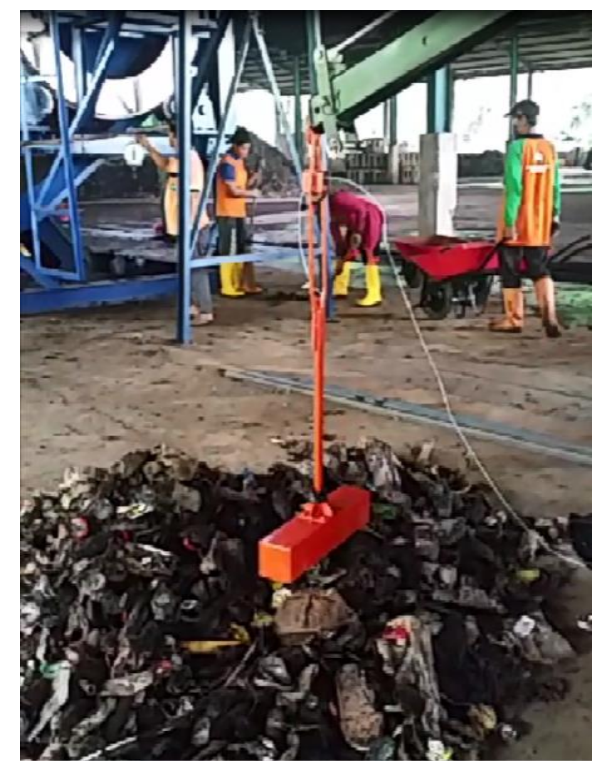

Gambar 8. Uji keempat dengan menggunakan sampah TPST Bantargebang dan diintegrasikan dengan sistem pretreatment PLT Sampah tahap akhir 
Dengan keempat uji tersebut, dapat dilihat bahwa rancangan desain inovasi pemisah logam yang dibuat kombinasi inti magnet ferrite dengan neodymium, yang dipasang derek menunjukkan kerja yang baik. Hanya saja memang terdapat beberapa kendala seperti: adanya sampah nonlogam yang ikut terbawa dalam proses pengumpulan akibat keberadaannya di antara sampah logam dengan magnet. Hal ini menjadi pekerjaan rumah bagi proses penyempurnaan dan pengoptimalisasian dari sistem ini. Meskipun biasanya sampah yang terbawa tidak signifikan, tetapi tetap pada akhirnya sampah ini harus dipisahkan dari sampah logam yang terkumpul.

Inovasi ini sebenarnya menjadi suatu hal yang baru jika dibandingkan dengan sistem pemisah logam di area pemilahan sampah yang telah digunakan berbagai negara selama ini. Karena pada umumnya, sampah logam dipisahkan dari campuran sampah padat kota dengan menggunakan unit pemroses pemisah logam yang secara permanen terpasang di lokasi tertentu dan dengan magnet pemisah elektromagnet yang pada operasinya menggunakan listrik sebagai sumber energi $(12,13,14,15)$. Sementara pada sistem ini, sistem pemisah logam dibuat secara mobil dan fleksibel sehingga bisa melakukan pemisahan logam pada bagian unit mana saja pada sistem pemrosesan sampah, baik itu dengan proses termal maupun sanitary landfill yang pada umumnya dijadikan opsi pembuangan sampah. Unit ini bisa dengan mudah diintegrasikan dengan unit pemroses yang telah ada atau bahkan bisa berdiri sendiri untuk tujuan pemisahan logam yang spesifik. Selain itu, penggunaan magnet permanen berintikan kombinasi ferrit dan neodymium tidak memerlukan listrik selama proses operasinya.

\section{KESIMPULAN}

Kombinasi inti magnet ferrite dengan neodymium dapat menghasilkan sistem pemisah logam yang efektif dengan daya pisah yang cukup baik. Selain itu, sifat mobil dengan pemilihan desain instalasi dengan derek dan mobil kabin ganda menambah nilai fleksibilitas dari sistem ini yang membuatnya mampu dioperasikan secara sendiri ataupun diintegrasikan dengan sistem pretreatment yang dimiliki oleh PLT Sampah TPST Bantargebang.

\section{PERSANTUNAN}

Peralatan didanai oleh dana DIPA PPTL 2018. Terima kasih disampaikan kepada Direktur PTL Dr. Rudi Nugroho dan Kabag PAPL PTL Dr. Muhammad Hanif yang telah memberikan dukungan dan arahan yang begitu maksimal kepada anggota tim pelaksana sehingga kegiatan dapat berjalan secara baik dan sesuai dengan yang direncanakan.

\section{DAFTAR PUSTAKA}

1. Chimenos, J. M., Segarra, M., Fernández, M., \& Espiell, F. (1999). Characterization of the bottom ash in municipal solid waste incinerator. Journal of hazardous materials, 64(3), 211-222

2. Fernandez, M. A., Martinez, L., Segarra, M., Garcia, J. C., \& Espiell, F. (1992). Behavior of heavy metals in the combustion gases of urban waste incinerators. Environmental science \& technology, 26(5), 1040-1047.

3. Li, Y., Zhang, H., Shao, L., Zhou, X., \& He, P. (2019). Impact of municipal solid waste incineration on heavy metals in the surrounding soils by multivariate analysis and lead isotope analysis. Journal of Environmental Sciences.

4. Phongphiphat, A., Ryu, C., Finney, K. N., Sharifi, V. N., \& Swithenbank, J. (2011). Ash deposit characterisation in a large-scale municipal waste-to-energy incineration plant. Journal of hazardous materials, 186(1), 218-226.

5. Li, W., Ma, Z., Huang, Q., \& Jiang, X. (2018). Distribution and leaching characteristics of heavy metals in a hazardous waste incinerator. Fuel, 233, 427441.

6. Ecke, H. (2003). Sequestration of metals in carbonated municipal solid waste incineration (MSWI) fly ash. Waste Management, 23(7), 631-640.

7. Fitzgerald, G. C. (2013). Pre-processing and treatment of municipal solid waste (MSW) prior to incineration. In Waste to Energy Conversion Technology (pp. 55-71). Woodhead Publishing.

8. Croat, J. J. (1997). Current status and future outlook for bonded neodymium permanent magnets. Journal of applied physics, 81(8), 4804-4809.

9. Kenny, G., \& Sommer Jr, E. J. (1984). A Simplified Process For Metal And NonCombustible Separation from MSW prior to Waste-To-Energy Conversion.

10. Rahman, M., \& Slemon, G. (1985). Promising applications of neodymium boron iron magnets in electrical machines. IEEE transactions on Magnetics, 21(5), 17121716.

11. Jung, H. (2005). U.S. Patent No. 6,854,777. 
Washington, DC: U.S. Patent and Trademark Office.

12. Rimaitytè, I., Denafas, G., Martuzevicius, D., \& Kavaliauskas, A. (2010). Energy and environmental indicators of municipal solid waste incineration: toward selection of an optimal waste management system. Pol. J. Environ. Stud, 19(5), 989.

13. Di Maria, F., Micale, C., Morettini, E., Sisani, L., \& Damiano, R. (2015).
Improvement of the management of residual waste in areas without thermal treatment facilities: A life cycle analysis of an Italian management district. Waste management, 44, 206-215.Chieffalo, R., \& Lightsey, G. R. (1996). U.S. Patent No. $5,506,123$. Washington, DC: U.S. Patent and Trademark Office.

14. Singh, N. D., France, R. G., Sambell, L. J., \& Poelzer, P. T. (2009). U.S. Patent Application No. 11/628,813. 